\title{
POCZUCIE MORALNOŚCI. PIĘĆ KODÓW ETYCZNYCH W PERCEPCJI WYCHOWANKÓW MŁODZIEŻOWYCH OŚRODKÓW WYCHOWAWCZYCH
}

Streszczenie: Problem moralności towarzyszył człowiekowi od wieków, człowiek, jako istota myśląca, dążył do poznania przyczyn swoich zachowań, pragnął ukierunkować swoją egzystencję w odniesieniu do świata norm i wartości moralnych. Wymiar moralny, w sposób istotny determinujący funkcjonowanie człowieka, jest częścią jego szeroko pojmowanej duchowości. Obserwując i oceniając działania innych ludzi, skupiamy się przede wszystkim na identyfikacji ich celów czy intencji (a więc analizujemy je w sensie ich działań), ponieważ wymaga tego atrybucja ich cech. Zmierzanie do określonych celów jest definicyjnym składnikiem wielu cech, a przypisywanie intencji - podstawowym elementem sądów moralnych. Tendencje takie skutkują skłonnością do analizowania zachowań innych ludzi w kategoriach moralnych. Własna sprawność jest dla człowieka niezwykle istotna z punktu widzenia skuteczności jego działania, a sprawność innego człowieka interesuje nas ze względu na to, czy jego działania przynoszą nam dobro, czy też nie (Peeters, Czapiński 1990). W niniejszym artykule zostały zaprezentowane wyniki badań nad percepcją pięciu kodów moralnych (Etyki: Godności, Kolektywizmu, Dobra Powszechnego, Produktywności), przeprowadzonych z wychowankami Młodzieżowych Ośrodków Wychowawczych z terenu woj. mazowieckiego.

Słowa kluczowe: moralność, wychowanie, pięć kodów moralnych, Młodzieżowe Ośrodki Wychowawcze.

\section{Uczucia moralne w świetle teorii Hoffmana}

Podstawy moralności kształtują się od najwcześniejszych lat życia dziecka, wspierane przez rozwój inicjatywy i angażowanie się w różne działania. W wyniku kształtowania się podstaw moralności pojawia się np. zawstydzenie, gdy dziecko zostaje przyłapane na łamaniu reguł, ale także czuje się winne w przypadku, kiedy nikt nie odkrył jego przewinień, ponieważ uważa, że inni znają jego uczynki (Smykowski 2006, s. 165-205). Etap, w którym pojawiają się pierwsze uczucia moralne, określany jest jako moralność heteronomiczna (Piaget 2006). Zdaniem Jeana Piageta, 
pojawiające się w tym czasie podporządkowanie narzuconym normom związane jest z jednostronnym szacunkiem i regułą przymusu. Źródłem rozwoju moralnego jest, jego zdaniem, szacunek, którym dziecko darzy rodziców i inne osoby dorosłe, uznając je za ważniejsze od siebie i mające władzę (moralność posłuszeństwa), a dzieci przestrzegają reguł moralnych, obawiając się kary. Lawrence Kohlberg (Papali, Olds 1986, s. 386) pisał, że dopiero w stadium operacji konkretnym kryterium oceny niewłaściwych uczynków stają się intencje, a postępowanie moralne uznawane jest za konieczne do społecznego współdziałania.

Zdaniem Martina L. Hoffmana, teoria zaproponowana przez Kohlberga nadmiernie akcentuje racjonalne procesy poznawcze jednostki. Struktura moralna jednostki została przez Hoffmana skonceptualizowana jako sieć uczuć empatycznych, reprezentacji poznawczych i motywów. Tworzą ją zasady, normy behawioralne, reguły, poczucie dobra i zła, poczucie popełnionego występku, a także obrazy własnych działań, które skrzywdziły innych lub im pomogły, wyobrażenie towarzyszących człowiekowi samooskarżeń i poczucia winy (Hoffman 2006, s. 127). Hoffman uznaje działania moralne za próbę uzyskania równowagi pomiędzy motywami egoistycznymi a moralnymi.

Teoria Hoffmana charakteryzuje ludzkie zachowania w pięciu sytuacjach (dylematach) moralnych:

- jednostka jest niezaangażowanym obserwatorem osoby cierpiącej (kwestia moralna: czy pomagam, a jeśli nie, to jak się z tym czuję?);

- jednostka jest sprawcą sytuacji, w której ktoś odczuwa krzywdę (pytanie: czy jednostka powstrzymuje się od działania, a jeśli nie, to czy ma poczucie winy?);

- jest wiele osób, które wysuwają roszczenia moralne (dylemat: komu pomogę i czy będę mieć wyrzuty sumienia z powodu nieudzielenia pomocy innym?);

- dylemat społeczeństw zróżnicowanych kulturowo: która zasada zwycięży: troska czy sprawiedliwość? Czy jednostka będzie miała poczucie winy z tego powodu, że naruszyła jedną z zasad?).

Hoffman wskazuje, że uczucie empatii jest możliwe wtedy, gdy jest zakorzenione w zgodnej z nią zasadzie etycznej. Uczucia empatyczne są związane z ważnymi zasadami świata zachodniego: troską i sprawiedliwością. Autor stawia tezę, że uczucie empatii składa się z dwóch elementów: pierwszy wywołany jest przez bodziec, cierpienie innego człowieka, a drugi - wzbudzony przez zasadę moralną (Hoffman 2006, s. 24). Reasumując, empatia może mieć wpływ na osąd moralny dotyczący nas lub innego człowieka w sposób bezpośredni lub pośredni poprzez zasady moralne, które uaktywnia. W procesie socjalizacji dzieci uwewnętrzniają takie wartości, jak sprawiedliwość i troska, co może wskazywać na późniejszy fakt istnienia w systemie motywacyjnym dorosłych, związanych z empatią, reguł troski i sprawiedliwości. „Istnieje więcej powodów, aby uważać moralność opartą na empatii za zjawisko uniwersalne, niż by uważać inaczej. Moralność oparta na empatii powinna promować zachowania prospołeczne i zniechęcać do agresji, w kulturach opartych na zasadzie troski oraz większości zasad sprawiedliwości” 
(Hoffman 2006, s. 30). Wielu badaczy, analizując rozwój moralny, podkreśla znaczenie procesów nieświadomych i systemu afektywnego czy też rozwoju empatii. Motywacją działania moralnego, według koncepcji M. L. Hoffmana, są umiejętności współodczuwania i respektowania potrzeb innych; jest to inna wizja moralności niż np. Kanta, Kolberga czy Piageta.

\section{Wychowanie moralne}

Problem moralności towarzyszył człowiekowi od wieków, człowiek, jako istota myśląca, dążył do poznania przyczyn swoich zachowań, pragnął ukierunkować swoją egzystencję w odniesieniu do świata norm i wartości moralnych. Wymiar moralny, w sposób istotny determinujący funkcjonowanie człowieka, jest częścią jego szeroko pojmowanej duchowości. Moralność, zdaniem Erwinga Goffmana (Goffman 2000), to ogół działań i sytuacji społecznych, którym sami działający aktorzy przypisują znaczenia. Florian Zaniecki definiuje moralność jako normy, wartości, sensy obecne w kulturze, Julia Diedier natomiast jako „naukę o dobru oraz zasadach ludzkiego postępowania” (Dieder 1996, s. 238). Do zakresu zadań pedagogiki zaliczyć można wspomaganie rozwoju moralnego człowieka, a więc wychowanie moralne. Mieczysław Łobocki pisze, że wychowanie moralne „ma na celu w szczególności rozwój moralny dzieci i młodzieży, w tym zwłaszcza przekazanie im wiedzy o problemach moralnych i rozwijanie umiejętności rozpoznawania tego, co złe, niegodziwe czy wręcz nikczemne z moralnego punktu widzenia. Uczy wrażliwości moralnej i gotowości do postępowania moralnego" (Łobocki 2005, s. 269). Definiowanie tego, co jest dobre, uniwersalne, prawdziwe, zależy od światopoglądu, kultury czy założeń filozoficznych. Różne są także stanowiska badaczy zajmujących się problematyką etyki. Łobocki uważa, że najistotniejsze dla fenomenu wychowania moralnego jest rozumienie związków pomiędzy stanowiskami na temat tego, co uznawane jest za moralne a określoną psychologią podmiotu moralnego. Odwołując się do literatury przedmiotu, mówi o dwóch znaczeniach w wychowaniu moralnym opisowym i oceniającym (Łobocki 2002, s. 14; 2005, s. 269). Celem wychowania moralnego w pierwszym znaczeniu (opisowym) jest zapoznanie się z różnymi rodzajami postępowania moralnego, rozwijanie świadomości moralnej wychowanków, uczenie ich umiejętności racjonalnego uzasadniania akceptowalnych norm i wartości, bez ujawniania własnych preferencji wychowawcy. „Szczególny nacisk kładzie się na logiczną i wystarczająco pogłębioną argumentację zajmowanego przez poszczególnych dyskutantów stanowiska" (Łobocki 2002, s. 14).

W znaczeniu oceniającym wychowawca ma za zadanie przekonać młodzież do akceptacji ogólnie uznawanych norm. „Stawia sobie za cel wpajanie dzieciom i młodzieży norm, zasad i wartości moralnych, których aprobata i realizacja ma zapewnić im to, żeby były moralne" (Łobocki 2002, s. 14). Jak pisze dalej Łobocki, „prawdopodobnie w praktyce pedagogicznej obie wersje wychowania moralnego 
mogą okazać się użyteczne. Zależy to m.in. od wieku, stopnia dojrzałości umysłowej i społecznej" (Łobocki 2002, s. 14-15). Problemy teorii wychowania dotyczące kształtowania moralności wychowanków w dużym stopniu dotyczą praktyki. Z tego powodu niezwykle ważne jest prowadzenie badań i opracowanie metodycznych rozwiązań, a także edukacja wychowawców i nauczycieli w zakresie wychowania moralnego dzieci i młodzieży.

\section{Zaburzenia rozwoju wartości moralnych u młodzieży niedostosowanej społecznie}

Dzieci, których potrzeby zależnościowe i afektywne nie były właściwie kształtowane, z powodu zaniedbania lub odrzucenia przez rodziców, nie mają podstaw do rozwoju norm społecznych (Reykowski 1980). Można przypuszczać, że powoduje to u nich zakłócenia w rozwoju emocjonalnym i rozwoju uczuć wyższych, niezwykle istotnych z punktu widzenia kształtowania się hierarchii wartości, co w rezultacie prowadzi do deficytu wartości moralnych. Kiedy rodzina nie spełnia swoich funkcji w zakresie wsparcia prawidłowego przywiązania u dziecka, moga pojawić się zaburzenia zachowania skutkujące negatywną socjalizacją. Może również dojść do nieprawidłowego rozwoju moralnego. Współczesne teorie na temat nieprzystosowania społecznego oceniają dojrzałe formy zachowań dewiacyjnych jako rezultat długotrwałego procesu, którego źródła należy szukać we wczesnym dzieciństwie (Urban 2000).

\section{Interpretacja zachowań moralnych}

„Wiele przesłanek pozwala sformułować tezę o dominacji kategorii moralnych w procesie spostrzegania innego człowieka (a więc z pozycji obserwatora), zaś sprawnościowych - w spostrzeganiu zachowań własnych (a więc z pozycji aktora). Wynika to, po pierwsze, $z$ różnicy celów poznawczych, jakie realizujemy, stając na pozycji aktora (a więc obserwując zachowania własne) lub obserwatora (obserwując zachowania cudze). Z pozycji aktora dążymy do osiągnięcia jakichś stanów rzeczy, co wymaga stałego monitorowania własnego działania z uwagi na to, jak dalece przybliża nas ono do założonego celu" (Wojciszke, Baryła 200o, s. 395-421). Obserwując i oceniając działania innych ludzi, skupiamy się przede wszystkim na identyfikacji ich celów czy intencji (a więc sensie ich działań), ponieważ wymaga tego atrybucja ich cech. Zmierzanie do określonych celów jest definicyjnym składnikiem wielu cech (za: Wojciszke, Baryła: Read i in. 1990), a przypisywanie intencji - podstawowym elementem sądów moralnych. Tendencje takie skutkują skłonnością do analizowania zachowania innych ludzi w kategoriach moralnych. Własna sprawność jest dla człowieka niezwykle istotna z punktu widzenia skuteczności jego działania, a sprawność innego człowieka interesuje nas ze względu na to, czy jego działania przynoszą nam dobro, czy też nie (Peeters, Czapiński 1990). 
Reakcje afektywne na innych ludzi różnią się w zależności od przypisywanych im cech. Najsilniejsze emocje (negatywne) budzi czyjaś niemoralność, słabsze (pozytywne) - czyjaś moralność. Moralne zachowanie osoby lubianej wzbudza pozytywne reakcje afektywne, etyczne natomiast zachowanie osoby nielubianej jest nam obojętne. Niemoralne zachowanie osoby lubianej budzi w nas bardziej negatywne emocje niż podobny postępek osoby nielubianej. Zawyżone szacowanie własnej moralności spowodowane jest tym, że w momencie realizacji celów nie myślimy o ich aspekcie moralnym, rozpatrując je jedynie w kategoriach sprawnościowych. Jeśli jednak z jakichś powodów uznamy własne postępowanie za niemoralne, to doświadczamy poczucia winy i je przerywamy. W ten sposób nie kontynuujemy działań, które uznajemy w momencie ich wykonywania za pozanormatywne, a skoro tak, nie mamy powodu, aby nisko oceniać własną moralność.

Co ciekawe u osób, z którymi łączy nas relacja symbiotyczna, zwykle za ważniejsze uznajemy cechy sprawcze. W jednym z badań uczestnicy ocenili znacznie wyżej cechy sprawcze niż wspólnotowe. W ocenie postępowania własnego prawnika ważniejsza dla nich była jego moralność niż kompetencje (odwrotnie było przy ocenie stanowiącego dla tegoż prawnika konkurencję) (Wojciszke 200o). Koncentracja na sprawczości własnych działań nie jest jednak jedynym czynnikiem hamującym nasze zaangażowanie w inne ich interpretacje. Z badań (Wojciszke 200o) wynika, że wydawanie sądów o sobie w dziedzinie moralności jest awersyjne. Powoduje to fakt, że wydobycie z pamięci semantycznej (obejmującej m.in. abstrakcyjną wiedzę o naszych cechach i predyspozycjach) informacji o jakiejś właściwości (np. „jestem uczciwy”) powoduje aktywizację pamięci epizodycznej, dotyczącej przeszłych zdarzeń naszego życia, a także treści niezgodnych z deklarowaną uczciwością czy moralnością. „Jest to wprawdzie zjawisko funkcjonalne, gdyż dzięki informacji wydobytej z pamięci epizodycznej jesteśmy w stanie ograniczyć stosowalność przesłanek podpowiadanych przez pamięć semantyczną w momencie, w którym mamy sformułować aktualny obraz «Ja», ale w tym konkretnym przypadku oznacza, że korzystnemu sądowi ogólnemu będzie zawsze towarzyszyć nieprzyjemne wspomnienie. Ponieważ ani źle o nas świadczących zdarzeń z przeszłości nie możemy zmienić, ani rozstać się z cennym dla nas przekonaniem, że jesteśmy osobą moralną, tkwimy w tej nierozwiązywalnej poznawczej rozbieżności, która powoduje ruminowanie, czyli uporczywe dręczenie się powracającymi negatywnymi myślami”" Jak wykazali Bogdan Wojciszke i Wojciech Baryła (2000; 2005), ruminacje pojawiają się jako efekt przypisywania sobie moralności, ale nie wtedy, gdy przypisujemy sobie sprawność. Prowadzi to także do chwilowego spadku samooceny i motywacji do jej podwyższenia, np. poprzez przypisanie sobie w większym stopniu pozytywnych cech sprawnościowych.

1 Z recenzji J. Klebaniuka książki B. Wojciszke (2010), Sprawczość i wspólnotowość. Podstawowe wymiary spostrzegania społecznego, Gdańsk: GWP. 
Innego rodzaju powszechnym zjawiskiem jest uznawanie za ogólnie moralne zachowań służących realizacji własnych interesów. Wytłumaczyć je można, odwołując się do bezwiednego egocentryzmu w interpretowaniu zachodzących zdarzeń (np. poprzez zakładanie, że inni wiedzą o nas to samo, co my), automatycznego wartościowania wszystkiego, z czym się spotykamy jako dobrego lub złego. Częściowo jest to również związane z wydawaniem ocen moralnych w sposób bezrefleksyjny, intuicyjny, bez rozumowania moralnego, w oparciu jedynie o automatyczną ewaluację. Wszystko to sprawia, że podstawą osądu moralnego staje się relacja danego zdarzenia do naszego interesu, ponieważ zaś jesteśmy osobą, która najbardziej intensywnie i konsekwentnie działa na rzecz własnego dobra, nic dziwnego - konkluduje B. Wojciszke (Wojciszke 200o) - że uznajemy się za osobę wysoce moralną.

\section{Koncepcja pięciu kodów moralnych}

Autorzy „Skali Etyk”, Bogdan Wojciszke i Wiesław Baryła, piszą, że modularność sądów moralnych zakłada, iż jednostka (ale także wspólnota) używa wielu kodów etycznych będących podstawą sądów moralnych. Każdy z takich kodów zbudowany jest wokół wartości głównej, funkcjonuje niezależnie od innych i charakteryzuje się typowymi dla siebie „cnotami” i „grzechami”. Istnieje prawdopodobieństwo, że wykorzystywane są alternatywnie, a nie jednocześnie.

Kody zostają zaktywizowanie za pomocą specyficznych kontekstów wywoławczych (sygnały). Do każdego kodu przypisane są pewne klasy zjawisk czy zachowań. Kryteria ich oceny, np. metodą Etyki Godności, może być kodem do oceny zachowań swoich (in- groups) a nie „obcych” (out-groups), w zależności od indywidualnego czy grupowego doświadczenia (Wojciszke, Baryła 2000, s. 398).

W związku z tym, że jednostka dysponuje wieloma kodami etycznymi, istnieją zróżnicowane sądy moralne, zależne od tego, kto, kiedy i w jakiej sytuacji postąpił w konkretny sposób. Może zasługiwać przez to na pozytywną lub negatywną ocenę moralną. $Z$ tezy o modularności sądów moralnych wynika, że aby opisać kody etyczne jakiegoś społeczeństwa, należy odnaleźć jego najbardziej typowe kody etyczne, a następnie stwierdzić, czy wyczerpują one całość ocen moralnych. Bogdan Wojciszke i Wiesław Baryła zaproponowali pięć kodów typowych dla społeczeństwa polskiego: Etykę Autonomii, Etykę Kolektywistyczną, Etykę Dobra Powszechnego, Etykę Godności i Etykę Produktywności (charakterystyka podstawowych własności tych kodów znajduje się w opisie Kwestionariusza etyk narzędzia badawczego). Z ich pomocą zostali zbadani wychowankowie Młodzieżowych Ośrodków Wychowawczych (MOW) z terenu województwa mazowieckiego.

\section{Charakterystyka grupy badanej}

W badaniu wzięło udział 456 osób w wieku od 17 do 20 lat $(\mathrm{M}=17,31 ; \mathrm{SD}=0,68)$. Zgodnie z ustawą, w MOW wychowankowie przebywają do 18 roku życia, ale 
badaniem zostały objęte również osoby starsze, będące w procesie usamodzielniania, przebywające w mieszkaniach chronionych lub filiach ośrodków.

W grupie badanych kobiety stanowiły 59,2 proc., mężczyźni natomiast 40,8 proc. Obecnie w 97 ośrodkach MOW w Polsce przebywa 5468 wychowanków: 3729 chłopców i 1733 dziewcząt (według danych Systemu Informacji Oświatowej SIO z 5 kwietnia 2016 roku, http://ore.edu.pl). Tak duża liczba dziewcząt biorących udział w badaniu wynika ze specyfiki ośrodków w województwie mazowieckim (sześć ośrodków tylko dla dziewcząt, pięć koedukacyjnych, dziewięć dla chłopców) oraz z tego, że w badaniach uczestniczyły osoby, które zgłosiły chęć wzięcia w nich udziału.

\section{Pytania badawcze}

- Jaki jest poziom moralności badanej grupy mierzony kodami etycznymi? Jakie są relacje pomiędzy moralnością mierzoną kodami etycznymi a płcią badanych?

- Jaka jest relacja pomiędzy dłuższym lub powtórnym pobytem w MOW a moralnością mierzoną kodami etycznymi?

- Jaka jest relacja pomiędzy moralnością a wynikami w nauce badanych osób?

\section{Metodyka badań}

Badania o charakterze ilościowym dostarczają informacji pozwalających na zestawienie danych w sposób umożliwiający znalezienie odpowiedzi na pytania wymagające szacunków i konstrukcji modeli probabilistycznych. Pomiar dokonany za pomocą tych metod umożliwia uzyskanie wieloczynnikowych charakterystyk statystycznych pozwalających na eksplorację, opis i wyjaśnienie problemu w parametryczno-wskaźnikowej analizie danych. Dlatego też badanie ilościowe jest wskaźnikowo ważną metodą gromadzenia informacji. Wymaga więc odpowiednio dobranej próby badawczej, zapewniającej reprezentatywność oraz poprawność wyciąganych wniosków.

\section{Badanie eksploracyjne}

Niniejsze badania mają charakter eksploracyjno-diagnostyczny, a więc pozwalają zarówno na dokonanie opisu danych empirycznych zebranych w trakcie badanie, jak również pozwalają wyjaśnić i przewidywać wystąpienie bądź nie danego zjawiska. Ze względu na wybór rodzaju badania (badania eksploracyjne) nie zdecydowano się na stawianie szczegółowych hipotez badawczych, lecz pozostano jedynie przy pytaniach badawczych. O słuszności takiego podejścia informuje m.in. Wątroba (2009) oraz Nowak i Łobocki (2001), tłumacząc to tym, że stawianie kierunkowych hipotez może utrudnić gromadzenie i analizę zebranych statystycznych. Ponadto stawianie hipotez badawczych rekomendowane jest głównie 
dla podejścia konfirmacyjnego (badań, gdzie podłożem jest testowanie hipotez zakładających występowanie konkretnych powiązań bądź zależności).

\section{Narzędzie badawcze - Kwestionariusz Etyk}

Narzędzie to służy do pomiaru stopnia identyfikacji z jednym z następujących kodów:

- Etyką Autonomii - wartością cenioną jest dobro innej jednostki. Do cnot kardynalnych zaliczają się: poszanowanie dobra, wolności i praw jednostki, pomaganie innym oraz lojalność. Grzechami głównymi są przede wszystkim krzywda innego człowieka oraz łamanie praw jednostki;

- Etyką Kolektywizmu - wartością cenioną jest dobro grupy własnej. Do cnot kardynalnych zalicza się poszanowanie dobra, interesu i praw grupy własnej. Grzechem głównym jest przede wszystkim działanie na szkodę grupy;

- Etyką Dobra Powszechnego - wartością cenioną jest dobro społeczności jako całości. Do cnot kardynalnych zalicza się poszanowanie norm, których beneficjentem jest społeczność. Grzechem głównym jest przede wszystkim łamanie praw społeczeństwa;

- Etyką Godności - wartością cenioną jest życie i funkcjonowanie w godny sposób. Do cnot kardynalnych zalicza się duchowość i honor. Grzechem głównym jest przede wszystkim pogoń za dobrami materialnymi, utrata „zdolności honorowej”;

- Etyką Produktywności - wartością cenioną jest produkcja dóbr. Do cnot kardynalnych zaliczają się: użyteczność, skuteczność, pracowitość i oszczędność. Grzechem głównym jest przede wszystkim bezproduktywność i lenistwo.

Poszczególne wymiary etyk są ze sobą skorelowane, jednak nie zagraża to trafności różnicowej skal. Trafność testowana była poprzez korelację akceptacji poszczególnych etyk ze zmiennymi psychologicznymi. Potwierdzono związek z prezentowaniem siebie w dobrym świetle (Kwestionariusz Aprobaty Społecznej); częściowo wykazano powiązanie Skal Etyk z zadowoleniem z życia oraz cenionymi własnościami pracy.

\section{Statystyczna analiza wyników}

Wszystkie obliczenia statystyczne zostały przeprowadzone w programie IBM SPSS Statistics. Do charakterystyki danych ilościowych zastosowano liczbę oraz procent obserwacji (zarówno ważony, jak i nie), do opisu natomiast informacji ilościowych użyto: średniej, odchylenia standardowego oraz wartości minimalnych i maksymalnych. Dodatkowo na etapie analizy danych wszystkie zmienne ilościowe poddano analizie pod kątem ich rozkładów, natomiast dane jakościowe analizowane pod względem równoliczności grup. Jako wynik istotny statystycznie uznano taki, gdzie szansa na popełnienie błędu I rodzaju jest mniejsza niż 5 proc. $(\mathrm{p}<0,05)$. Poniżej przedstawiono analizy zastosowane w niniejszym opracowaniu: 
- test U Manna-Whitneya (nieparametryczny odpowiednik testów $t$ dla prób niezależnych);

- korelacja rho Spearmana;

- analiza regresji liniowej metodą wprowadzania.

\section{Wyniki badania Kwestionariuszem Etyk}

W Kwestionariuszu Etyk wszystkie zmienne posiadają rozkład zbliżony do normalnego. Oznacza to, że największą część wyników stanowiły wyniki przeciętne. Podstawowe statystyki opisowe wraz z wyliczonymi miarami rozkładu przedstawiono w tabeli poniżej.

Tabela 1. Skala Etyk - statystyki opisowe

\begin{tabular}{|l|c|c|c|c|c|c|}
\hline & Min. & Max. & M & SD & Skośność & Kurtoza \\
\hline $\begin{array}{l}\text { Skala Etyki } \\
\text { Autonomii }\end{array}$ & $-1,2$ & 2,6 & 1,18 & 0,77 & $-0,62$ & $-0,48$ \\
\hline $\begin{array}{l}\text { Skala Etyki } \\
\text { Kolektywizmu }\end{array}$ & -2 & 3 & 1,34 & 0,91 & $-0,54$ & $-0,71$ \\
\hline $\begin{array}{l}\text { Skala Etyki } \\
\text { Dobra } \\
\text { Powszechnego }\end{array}$ & -3 & 3 & 1,11 & 0,97 & $-0,28$ & $-0,22$ \\
\hline $\begin{array}{l}\text { Skala Etyki } \\
\text { Godności }\end{array}$ & -2 & 3,1 & 1,15 & 0,81 & $-0,44$ & $-0,49$ \\
\hline $\begin{array}{l}\text { Skala Etyki } \\
\text { Produktywności }\end{array}$ & $-2,4$ & 3 & 1,06 & 0,85 & $-0,45$ & $-0,24$ \\
\hline
\end{tabular}

Źródło: opracowanie własne.

Za pomocą analizy korelacji $r$ Pearsona wykazano również, że wszystkie skale etyk skorelowane są ze sobą dodatnio (powiązania istotne statystycznie na poziomie $\mathrm{p}<0,001)$.

Pod względem rzetelności (testowanej za pomocą współczynnika Alfa Cronbacha) wszystkie skale okazały się wysoce spójne i mogą być z powodzeniem stosowane w badaniach naukowych oraz diagnozie indywidualnej:

- Skala Etyki Autonomii: 0,777;

- Skala Etyki Kolektywizmu: o,880;

- Skala Etyki Dobra Powszechnego: o,880;

- Skala Etyki Godności: 0,824;

- Skala Etyki Produktywności: o,868. 
Kolejnym etapem była charakterystyka uzyskanych wyników w grupie badanych. Przyjęto następujący podział wyników: niskie (<-1,01), przeciętne (-1 do 1), podwyższone $(1,01$ do 1,99), wysokie $(>2)$. Okazało się, że wyniki uzyskane w grupie badanych należy traktować jako podwyższone. Dokładną charakterystykę przedstawiono w tabeli 7. Najwyższy odsetek wyników wysokich uzyskano w przypadku Skali Etyki Kolektywizmu (31,9 proc.) oraz „Dobra Powszechnego” (23,2 proc.).

Tabela 2. Skala Etyk - podział wyników zgodnie z przyjętymi normami (w proc.)

\begin{tabular}{|l|c|c|c|c|c|}
\hline & \multicolumn{5}{|c|}{ Skala Etyk } \\
\cline { 2 - 6 } & Autonomii & $\begin{array}{c}\text { Kolekty- } \\
\text { wizmu }\end{array}$ & $\begin{array}{c}\text { Dobra } \\
\text { Powszechnego }\end{array}$ & Godności & $\begin{array}{c}\text { Produkty- } \\
\text { wności }\end{array}$ \\
\hline Niskie & 0,5 & 0,2 & 0,9 & 0,2 & 0,5 \\
\hline Przeciętne & 35,3 & 35,6 & 42,9 & 37,5 & 40,5 \\
\hline $\begin{array}{l}\text { podwyż- } \\
\text { szone }\end{array}$ & 51 & 32,3 & 32,9 & 49,7 & 46,3 \\
\hline wysokie & 13,2 & 31,9 & 23,2 & 12,6 & 12,7 \\
\hline ogółem & 100 & 100 & 100 & 100 & 100 \\
\hline
\end{tabular}

Źródło: opracowanie własne.

Wysokie wyniki w Skali Kolektywizmu mogą świadczyć o dużym poczuciu wspólnotowości, co jest bardzo pożądaną cechą, jeżeli nie jest źle pojmowaną solidarnością wobec grupy (np. grupy przestępcze). Etyka Kolektywizmu wiąże się bezpośrednio z poczuciem bezpieczeństwa jednostki. Wysokie wyniki w Skali Dobra Powszechnego: poszanowanie norm, których beneficjentem jest społeczność, z jednej strony mogą być oceniane jako wynik oddziaływań resocjalizacyjnych w ośrodku, a z drugiej należy wziąć pod uwagę pewne dewiacyjne formy zachowań, takie jak lojalność wobec rodziny pochodzenia wychowanków, bez względu na jej dysfunkcyjność i patologię grup rówieśniczych, nie zawsze funkcjonujących zgodnie z normami społecznymi.

\section{Zależność między analizowanymi zmiennymi a płcią}

Za pomocą analizy testem U Manna-Whitneya zbadano, czy istnieje zależność między analizowanymi zmiennymi a płcią badanych. Szczegółowe wyniki zamieszczono w tabeli 3, a poniżej - uzyskane wyniki. 
Tabela 3. Zależność między analizowanymi zmiennymi a płcią - wynik testu U Manna-Whitneya

\begin{tabular}{|l|c|c|c|c|c|c|}
\hline \multirow{2}{*}{} & \multicolumn{2}{|c|}{ Kobieta } & \multicolumn{2}{c|}{ Mężczyzna } & \multicolumn{2}{c|}{ Różnica } \\
\cline { 2 - 7 } & $\mathrm{M}$ & $\mathrm{SD}$ & $\mathrm{M}$ & $\mathrm{SD}$ & $\mathrm{U}$ & $\mathrm{p}$ \\
\hline $\begin{array}{l}\text { Skala Etyki } \\
\text { Autonomii }\end{array}$ & 1,35 & 0,70 & 0,95 & 0,79 & 15048,0 & 0,000 \\
\hline $\begin{array}{l}\text { Skala Etyki } \\
\text { Kolektywizmu }\end{array}$ & 1,49 & 0,85 & 1,14 & 0,93 & 16874,0 & 0,000 \\
\hline $\begin{array}{l}\text { Skala Etyki } \\
\text { Dobra }\end{array}$ & & & & & & \\
Powszechnego & 1,32 & 0,96 & 0,85 & 0,92 & 15100,5 & 0,000 \\
\hline $\begin{array}{l}\text { Skala Etyki } \\
\text { Godności }\end{array}$ & 1,33 & 0,73 & 0,91 & 0,83 & 15151,5 & 0,000 \\
\hline $\begin{array}{l}\text { Skala Etyki } \\
\text { Produktywności }\end{array}$ & 1,24 & 0,74 & 0,82 & 0,92 & 15950,0 & 0,000 \\
\hline
\end{tabular}

Źródło: opracowanie własne.

W przypadku Skal Etyk istotne różnice ze względu na płeć badanych zaobserwowano na każdej ze skal (różnice istotne na poziomie $p<0,001)$. Kobiety uzyskiwały znacznie wyższe wyniki niż mężczyźni, co graficznie przedstawiono na poniższym wykresie.

Wykres 1. Średnie Skal Etyk w zależności od płci

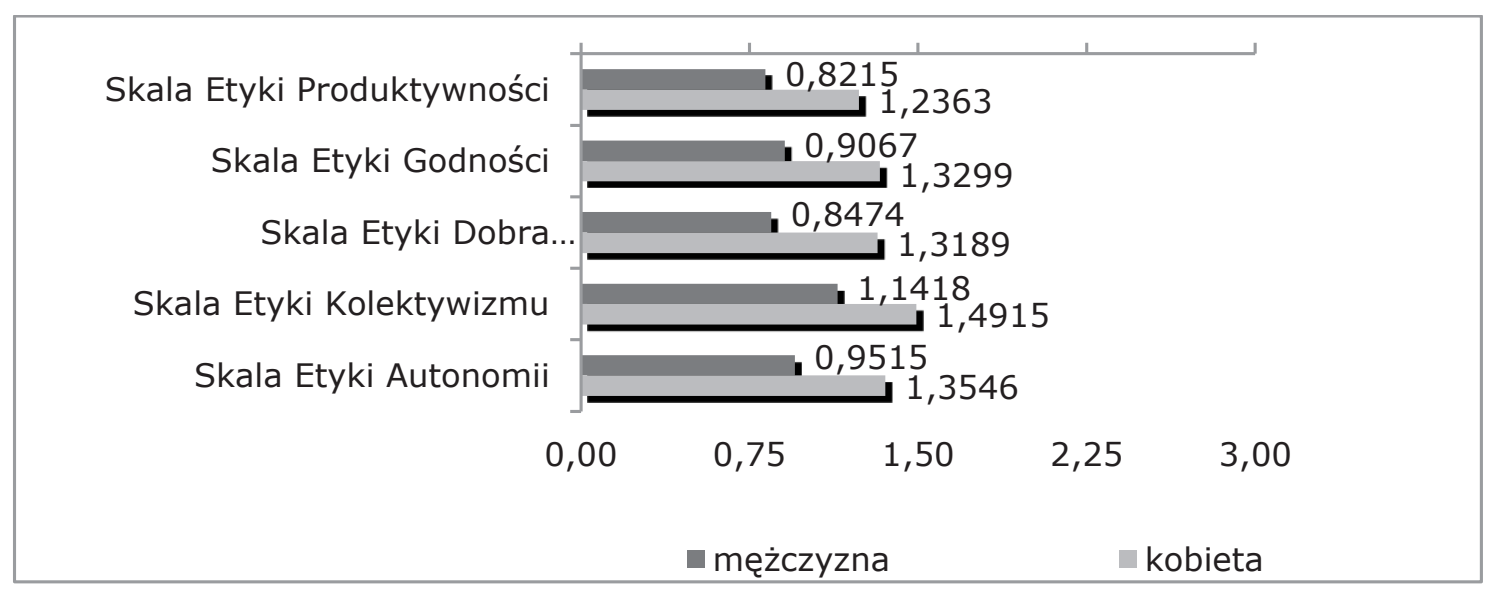

Źródło: opracowanie własne.

Wyniki wszystkich Skal Etyk (uzyskane na podstawie deklaracji badanych) wskazują na to, że dziewczęta charakteryzują się wyższym poczuciem moralnym niż chłopcy, co prawdopodobnie jest efektem odmiennej drogi socjalizacji dla płci. 
Można przypuszczać, że dziewczęta, będące wychowankami MOW, mają szanse na dobre funkcjonowanie społeczne w przyszłości. Jednocześnie można przypuszczać, że wcześnie podjęta interwencja resocjalizacyjna (u nastolatków, wychowanków MOW) może dać pozytywne rezultaty. Im później rozpoczęto oddziaływania, tym trudniejsze uzyskanie pozytywnej zmiany.

\section{Związek między analizowanymi zmiennymi a wynikami w nauce}

Za pomocą analizy korelacji rho Spearmana zbadano, czy istnieje związek pomiędzy analizowanymi zmiennymi a wynikami w nauce badanej młodzieży. Otrzymane wyniki pokazały, że im wyższe oceny uzyskiwano, tym wśród badanych obserwowano wyższe wyniki na skalach: Etyki Autonomii, Etyki Godności, Etyki Produktywności; ponadto badani byli wówczas bardziej sumienni i ekstrawertywni. Relacja pomiędzy wynikami w nauce a poczuciem moralności może wynikać z tego, że wraz z rozwojem intelektualnym (poznawczym) wzrasta świadomość norm społecznych i następuje rozwój potrzeb związanych z własnym rozwojem. Wyniki takie najprawdopodobniej świadczą o pozytywnych zmianach na skutek oddziaływań resocjalizacyjnych. Z drugiej strony, być może osoby, które uzyskują wyższe wyniki w nauce, już przed pobytem w MOW charakteryzowały się wyższym poziomem poznawczym i moralnym. Natomiast osoby mające niskie wyniki zarówno w nauce, jak i w Skałach Etyk, nie uwewnętrzniły jeszcze norm społecznych i wymagają oddziaływań resocjalizacyjnych w tej sferze oraz symulacji dotyczącej własnego rozwoju. Pozostałe korelacje okazały się nieistotne statystycznie. Szczegółowe wyniki przedstawiono w tabeli 4.

Tabela 4. Związek między analizowanymi zmiennymi a wynikami w nauce - wartości współczynników korelacji rho Spearmana

\begin{tabular}{|l|c|c|}
\hline & Ocena & p \\
\hline Skala Etyk Autonomii & 0,101 & 0,044 \\
\hline Skala Etyk Kolektywizmu & 0,060 & 0,231 \\
\hline Skala Etyk Dobra Powszechnego & 0,096 & 0,057 \\
\hline Skala Etyk Godności & 0,124 & 0,014 \\
\hline Skala Etyk Produktywności & 0,124 & 0,014 \\
\hline
\end{tabular}

Źródło: opracowanie własne.

\section{Zależność między analizowanymi zmiennymi a ilością pobytów w MOW}

Za pomocą analizy testem U Manna-Whitney’a sprawdzono, czy osoby przebywające w MOW po raz pierwszy różnią się od badanych przebywających w MOW co 
najmniej po raz drugi. Uzyskane wyniki pokazały, że pod względem większości analizowanych zmiennych nie potwierdzono istnienia różnic pomiędzy porównywanymi grupami. Wynika więc stąd, że osoby, które ponownie zostały umieszczone w MOW, nadal prezentują objawy charakterystyczne dla nieprzystosowania społecznego, co oznacza, że dotychczasowe oddziaływania resocjalizacyjne nie przyniosły oczekiwanych efektów.

Tabela 5. Zależność między analizowanymi zmiennymi a ilością pobytów w MOW - wynik testu U Manna-Whitneya

\begin{tabular}{|l|c|c|c|c|c|c|}
\hline \multirow{2}{*}{} & \multicolumn{2}{|c|}{ Pierwszy raz } & \multicolumn{2}{c|}{ Drug i kolejny } & \multicolumn{2}{c|}{ Różnica } \\
\cline { 2 - 7 } & $\mathrm{M}$ & $\mathrm{SD}$ & $\mathrm{M}$ & $\mathrm{SD}$ & $\mathrm{U}$ & $\mathrm{p}$ \\
\hline $\begin{array}{l}\text { Skala Etyki } \\
\text { Autonomii }\end{array}$ & 1,21 & 0,76 & 1,11 & 0,79 & 16227,5 & 0,175 \\
\hline $\begin{array}{l}\text { Skala Etyki } \\
\text { Kolektywizmu }\end{array}$ & 1,36 & 0,89 & 1,28 & 0,95 & 16957,5 & 0,476 \\
\hline $\begin{array}{l}\text { Skala Etyki Dobra } \\
\text { Powszechnego }\end{array}$ & 1,14 & 0,95 & 1,03 & 1,05 & 16494 & 0,348 \\
\hline $\begin{array}{l}\text { Skala Etyki } \\
\text { Godności }\end{array}$ & 1,17 & 0,79 & 1,08 & 0,87 & 16302 & 0,354 \\
\hline $\begin{array}{l}\text { Skala Etyki } \\
\text { Produktywności }\end{array}$ & 1,10 & 0,82 & 0,95 & 0,94 & 16057 & 0,170 \\
\hline
\end{tabular}

Źródło: opracowanie własne.

\section{Wynik analizy skupień}

Za pomocą analizy skupień metodą $k$-średnich wyodrębniono dwie grupy (optymalna liczba skupień została wyodrębniona za pomocą miary Silhouette, określającej spójność i odrębność grup). Pierwsza grupa $(n=136)$ charakteryzuje badanych $z$ niskimi wynikami na Skalach Etyk, natomiast druga grupa $(n=256)$ opisuje osoby z wysokimi wynikami na Skalach Etyk. Nie wykazano, aby przynależność do skupień zależała od liczby pobytów w MOW $\left(\operatorname{chi}^{2}(9)=7,21 ; p>0,05\right)$. Okazało się jednak, istotna zależność wystąpiła w przypadku płci $\left(\mathrm{chi}^{2}(1)=24,82 ; p<0,001\right)$. Zaobserwowano, że do skupienia pierwszego włączano więcej mężczyzn niż kobiet (57,6 proc.), w przypadku skupienia drugiego zaobserwowano odwrotną zależność (por. wykres 2). 
Wykres 2. Zależność między płcią a klasyfikacją do skupień

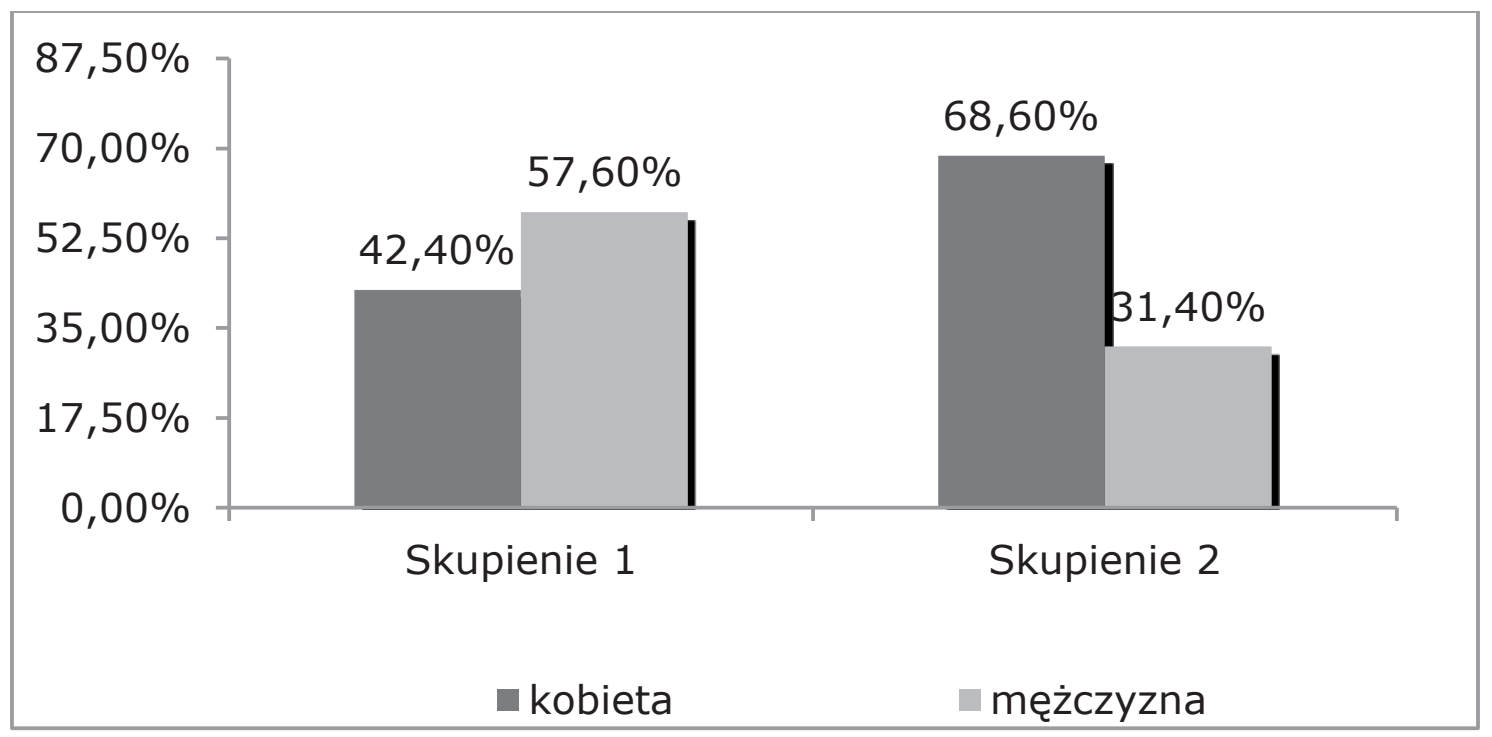

Źródło: opracowanie własne.

Z badań wynika że 42,40 proc. dziewcząt i 57,60 proc. chłopców uzyskało bardzo niskie wyniki na wszystkich Skalach Etyk, co jest charakterystyczne dla młodzieży z nieprzystosowaniem społecznym. Wskazuje to na potrzebę oddziaływań resocjalizacyjnych w celu uwewnętrznienia norm moralnych i społecznych. Można przypuszczać, że osoby ze skupienia drugiego, które uzyskały wysokie wyniki w Skali Etyk (skupienie 2 - 31,40proc. chłopców i 68,60 proc. dziewcząt), zinternalizowały normy moralne (przynajmniej tak wynika $\mathrm{z}$ ich deklaracji), co może świadczyć o tym, że mają szanse na dobre funkcjonowanie społeczne po opuszczeniu placówki.

\section{Interpretacja wyników}

Wyniki świadczące o wyższej etyczności dziewcząt mogą wynikać z ich odmiennej drogi socjalizacyjnej. Pojęcie różnic międzypłciowych znacznie wykracza poza biologię i obejmuje mechanizmy poznawcze i percepcyjne, poprzez które biologiczne zróżnicowanie zostaje przełożone na zróżnicowanie społeczne. Różnice istnieją także w sferze życia rodzinnego, kultury czy polityki. Przykładem tego zjawiska może być wspomniana już odmienna droga socjalizacji obu płci oraz inne oczekiwania społeczne wobec mężczyzn i kobiet. Większość badań potwierdza znaczne zróżnicowanie chłopców i dziewcząt w wielu aspektach (Remplein 1966, s. 542; Promp 1990, s. 88). Potocznie uważa się, że istnieją określone zachowania, charakteryzowane jako „typowo męskie” czy „typowo kobiece”, co tłumaczone jest różnicami biologicznymi. Stwierdzając: „jestem kobietą” czy „jestem mężczyzną”, wysyłamy jasny komunikat. Informacja w nim zawarta wykracza poza dziedzinę biologii - zawiera odwołanie się do cech osobowości, temperamentu oraz sposobu 
zachowania (Renzetti, Curran 2008). Efektem rozróżnienia płci biologicznej i płci kulturowej jest wyodrębnienie elementów będących częścią tożsamości człowieka, ale także takich, które są zależne od szeroko rozumianego kontekstu: społeczno-kulturowo-historycznego. Społecznie zdefiniowane cechy rodzajowe wpływają na odmienne postrzeganie cech i zachowania kobiet i mężczyzn. „Człowiek zaspokaja swoje potrzeby, rozwija potencjały (biologiczne, psychiczne, społeczne) w zgodzie z wymaganiami otoczenia" (Sęk 2001, s. 49). Zadania kobiety tradycyjnie definiowane są w odniesieniu do relacji z innymi ludźmi, z których największe znaczenie przypisuje się małżeństwu (Mandal 2003, 2004). Podczas procesu wychowania dziewczynki uczone są interpersonalnych umiejętności oraz wyższości takich uczuć, jak: przywiązanie, bliskość, empatia, troska, odpowiedzialność za związki interpersonalne (Jacoby 1995, za: Brannon 2002, Mandal 2004). Konsekwencją zróżnicowanej ze względu na płeć socjalizacji jest uczenie dziewcząt przejmowania odpowiedzialności za relacje (związki) i pełnienie w nich funkcji opiekunek (Fitzpatrick, Sollie 1999). Mężczyźni postrzegają sytuacje związane z bliskością w kategoriach zagrożenia ich władzy oraz słabości (Mandal 2004). Od chłopców nie oczekuje się skupienia na relacjach, ale na przygotowaniu do pracy zawodowej w celu uzyskania później możliwości utrzymania rodziny (Jacoby 1995, za: Mandal 2004). Jeśli chodzi o zachowania związane z emocjami, wymaga się raczej od chłopców ukrywania emocji niż ich ujawniania. W rezultacie mają mniejszą potrzebę angażowania się w relacje i nawiązywania bliskich więzi (Plopa 2002). Badacze formułowali swoje koncepcje dotyczące specyfiki płci w takich kwestiach, jak: niezależność, rywalizacja, osiągnięcia i definiowanie zasad kierujących zachowaniem, mniejszą wage przywiązując do znaczących dla kobiet cech: empatii, przywiązania i opieki (Jean Piaget, Eric Erickson i Lawrens Kohlberg). Wiąże się to $\mathrm{z}$ niejednakowym tempem rozwoju obu płci pod względem psychofizycznym i odmienną drogą socjalizacji ze względu na płeć. W okresie adolescencji dziewczęta szybciej niż chłopcy realizują zadania rozwojowe w obszarze budowania trwalszych i dojrzalszych relacji z rówieśnikami obu płci, osiągania roli społecznej, zdobywania niezależności od rodziców i innych dorosłych, przygotowania do życia w rodzinie i małżeństwa (Waldowski 2002). Ze względy na inną drogę socjalizacyjną cechuje je większa moralność i wspólnotowość niż chłopców w tym samym wieku. Chłopcy w okresie adolescencji ze względu na realizację celów rozwojowych bardziej nastawieni są na własną sprawczość.

W niniejszych badaniach nie wykazano zróżnicowania wyników na Skalach Etyk pomiędzy wychowankami MOW przebywającymi w ośrodku po raz pierwszy i tymi, którzy trafili tam po raz kolejny. Oznacza to, że podczas poprzedniego pobytu oddziaływania resocjalizacyjne nie przyniosły oczekiwanych efektów. Wyniki badań wskazują także na zależność wyników w nauce i przekonań moralnych wychowanków MOW. Badania potwierdzają tezy wielu autorów, że w momencie wzrostu motywacji do nauki i rozwoju świadomości młodego człowieka rosną potrzeby dotyczące samorealizacji, a także uwewnętrzniają się wartości i normy. 
W praktyce resocjalizacyjnej należy zwrócić większą uwagę na stymulowanie rozwoju poznawczego i emocjonalnego młodzieży. Potwierdza to słuszność koncepcji oddziaływań twórczych w resocjalizacji (Konopczyński 2009), ale także szeroko pojętego wsparcia duchowego, którego pozytywne efekty można zaobserwować np. w ośrodku prowadzonym przez księży orionistów.

\section{Bibliografia}

Abele A., Wojciszke B. (2014). Communal and agentic content in social cognition: A Dual Perspective Model, „Advances in Experimental Social Psychology”, nr 50, s. 195-255.

Banks M. (2009). Materiały wizualne w badaniach jakościowych. seria: „Niezbędnik Badacza”. Warszawa: Wydawnictwo Naukowe PWN.

Bartkowiak A. (2013). Sens życia $w$ teorii $i$ badaniach naukowych. Leszno: Wydawnictwo WSH.

Baumann K. (2009). Religiöser Glaube, personliche Spiritualität und Gesundheit. Überlegungen und Fragen im interdisziplinären Feld von Theologie und Religionswissenschaft, Medizin und Psychoterapie. „Zeitschrift für Medizinische Ethik", nr 55, s. 131-144.

Brannon L. (2002). Psychologia rodzaju, Kacmajor M. (tłum.). Gdańsk: GWP.

Böhm W. (2002). Über die Unvereinbarkeit von Erziehung und Therapie. „Vierteljahresschrift für wissenschaftliche Pädagogik”, nr 2, Jg. 78, s. 127-151.

Collins W. A., Sroufe, L. A. (1999). Capacity for intimate relationships. The development of romantic relationships in adolescence. USA: Cambridge University Press, s. 125-147.

Fitzpatrick J., Sollie D. (1999). Unrealistic Gender and Relationships to Investments and Commitment in Dating Relationships. "Journal of Social and Personal Relationship", 6, s. 852-86.

Friske S. T., Cuddy A. J., Glick P. (2007). Universal dimensions of social cognition: Warmth and competence. „Trend in Cognitive Science”, nr 11, s. 77-83.

Gilligan C. (1984). Die andere Stimme. lebenskonflikte und Moral der Frau. München, Zürich: Piper.

Głuchowska-Bogacka O. (2002). Poziom realizacji zadań rozwojowych w okresie wczesnej adolescencji (13-17 rok życia). W: Brzezińska A., Bardziejewska M., Ziółkowska B. (red.). Szanse rozwoju w okresie dorastania, Poznań: Wydawnictwo Fundacji Humaniora.

Goffman E. (200o). Człowiek w teatrze życia codziennego, Datner-Śpiewak H., Śpiewak P. (tłum.), Szacki J. (oprac. i słowem wstępnym opatrzył), wyd. I -. Warszawa 1977: PIW, Biblioteka Myśli Współczesnej; wyd II - Warszawa: Wydawnictwo Aletheia.

Harwas-Napierała B. (2012), Dorosłość jako spełnienie. Drogi i zagrożenia rozwoju człowieka w okresie dorosłości. Kraków: Libron-Filip Lohner. 
Heitger M. (1983), Beiträge zu einer Pädagogik des Dialogs, Eine Einführung. Mit einem Beitrag von Ines M. Breinbauer. Wien: Österreichischer Bundesverlag.

Kasser T., Ryan R. M. (1993), A dark side of the American dream: Corre-lates of financial success as a central life aspiration. "Journal of Personality and Social Psychology", nr 65, s. 410-422.

Kohlberg L. (1981). Essays on Moral Development. T. I. The Philosophy of Moral Development: Moral Stages and Idea of Justice, NY: Harper and Row.

Konopczyński M. (2009). Metody twórczej resocjalizacji. Teoria i praktyka wychowawcza, Warszawa: Wydawnictwo Naukowe PWN.

Łobocki M. (2002). Wychowanie moralne w zarysie. Kraków: Oficyna Wydawnicza „Impuls".

Łobocki M. (2005). Teoria wychowania w zarysie. Kraków: Oficyna Wydawnicza „Impuls”.

Mandal E. (2004), Podmiotowe i interpersonalne konsekwencje stereotypów zwiazanych z płcia, Katowice: Wydawnictwo Uniwersytetu Śląskiego.

Michalski J. T. (2011). Sens życia a pedagogika. Impulsy myśli Viktora E. Frankla. Toruń: Wydawnictwo Naukowe Uniwersytetu im. Mikołaja Kopernika.

Marczak M. (2011), Rodzaje płci w psychopatologii, W: Płeć i gender, Między ciałem umysłem a społeczeństwem, Palus K. (red.), Poznań: Wydawnictwo Naukowe UAM.

Olechnicki K., Załęcki P. (2004). Słownik Socjologiczny, Toruń: Wydawnictwo Graffiti.

Peeters G., Czapiński J. (1990). Positive-negative asymmetry in evaluative: The distinctions between affective and informational negativity effects, „European Review of Social Psychology", nr 1, s. 33-6o.

Plopa M. (2002). Doświadczenie intymności a satysfakcja z małżeństwa. „Małżeństwo i Rodzina", nr 3 (3), s. 22-26.

Plopa M. (2003). Intymność a „jej” i „jego" satysfakcja ze związku małżeńskiego, W: Janicka I., Rostowska T. (red.). Psychologia w służbie rodziny. Łódź: Wydawnictwo Uniwersytetu Łódzkiego, s. 32-44.

Promp D.W. (1990). Sozialisation und Ontogenese. Berlin-Hamburg.

Remplein H. (1966). Die seelische Entwicklung des Menschen im Kindes- und Jugend - alter, München-Basel. „E. Reinhardt”.

Renzetti C. M., Curran D. J. (2008). Kobiety, mężczyźni, społeczeństwo. Gromkowska-Melosik A. (tłum.). Warszawa: PWN.

Sęk H. (2001). Wprowadzenie do psychologii klinicznej. Warszawa: Wydawnictwo Naukowe Scholar.

Szanse i zagrożenia rozwoju w okresie dorosłości (2007). Brzezińska A. I., Appelt K., Wojciechowska J. (red.). Poznań: Wydawnictwo Fundacji Humaniora, s. 55-84. Urban B. (2000). Zaburzenia w zachowaniu i przestępczość młodzieży. Kraków: Wydawnictwo Uniwersytetu Jagiellońskiego.

Urban B. (2015). Agresja młodzieży i odrzucenie rówieśnicze. Warszawa: PWN. 
Waldowski K. (2002). Realizacja zadań rozwojowych na przełomie późnej adolescencji i wczesnej dorosłości. W: Szanse i zagrożenia rozwoju w okresie dorosłości, Brzezińska A., Appelt K., Wojciechowska J. (red.). Poznań: Wydawnictwo Fundacji Humaniora.

Wojciszke B., Baryła W. (200o). Potoczne rozumienie moralności - pięć kodów etycznych i narzędzie ich pomiaru. „Przegląd Psychologiczny”, t. 43, s. 395-421.

Wojciszke B., Szlendak M. (2010). Skale do pomiaru orientacji sprawczej $i$ wspólnotowej. „Psychologia Społeczna”, t. 5, s. 57-70.

\title{
MORAL SENSE. FIVE ETHICAL CODES IN PERCEPTION OF PUPILS OF THE EDUCATIONAL YOUTH CENTRES
}

\begin{abstract}
Man has been tackling the question of morality for centuries. It is because man, as a thinking being, has pursued the reasons for his or her behaviour and has wanted to focus his or her existence on the world of standards and moral values. The moral domain, which significantly determines the way people function, is part of broader spirituality. While observing and judging other people's actions, we concentrate primarily on identifying their goals or intentions (we analyse them in terms of their actions), because it is required by the attribution of their personality traits. It is a definitional component of many traits to pursue specific goals (Wojciszke, Baryła: Read, Jones, Miller, 1990), whereas the basic element of moral judgment is to assign intentions. As a result, we tend to analyse other people's behaviour in moral terms. Self-efficacy is particularly important for us in terms of effectiveness in our actions, whearas an interest in efficacy of other people shows our need to know if we can benefit or not from their actions (Peeters, Czapiński, 1990).

The article describes the results of a research on the perception of the five ethical codes (ethic of autonomy, ethic of dignity, ethic of community, ethic of common good and ethic of productivity) in pupils of the Youth Educational Centres in Mazovia Province.
\end{abstract}

Keywords: morality, education, five ethical codes, Educational Youth Centres.

Karina Szafrańska - doktor nauk humanistycznych, zastępca kierownika Zakładu Logopedii i Pedagogiki Specjalnej w Pedagogium - Wyższej Szkole Nauk Społecznych w Warszawie. Główne zainteresowania naukowe obejmują problematykę zaburzeń komunikacji, zaburzeń w rozwoju dzieci i młodzieży i profilaktyki zachowań ryzykownych. Adres do korespondencji: Pedagogium - Wyższa Szkoła Nauk Społecznych, ul. Marszałkowska 115, oo-102 Warszawa. Adres e-mailowy: karina.szafranska@sonica.com.pl. 